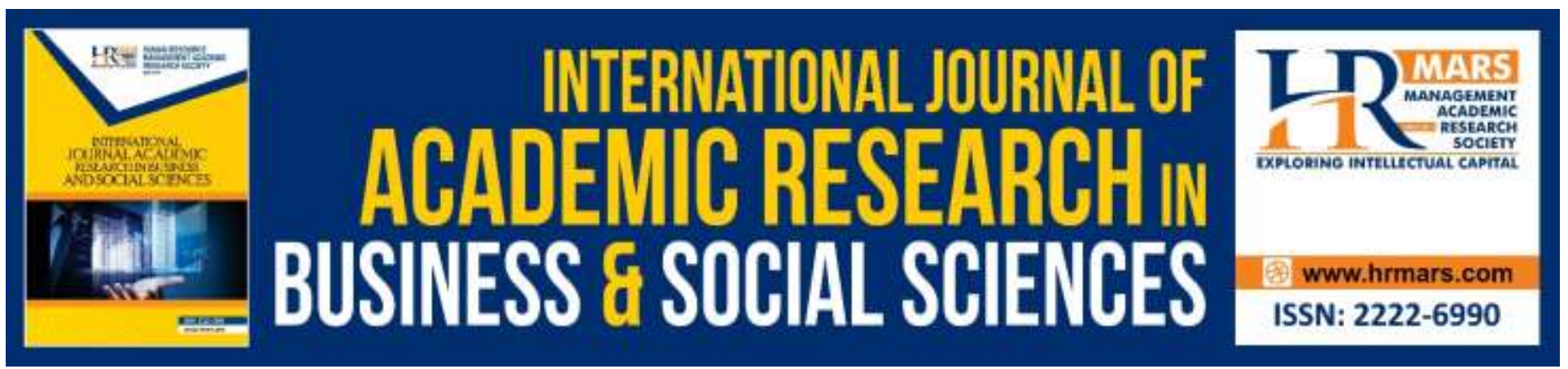

\title{
Rukhsah of Prayer for Officials of Flood Victims
}

\section{Abu Hasan Ashaari Sapai \& Basri Ibrahim}

To Link this Article: http://dx.doi.org/10.6007/IJARBSS/v10-i4/7144

DOI:10.6007/IJARBSS/v10-i4/7144

Received: 24 February 2020, Revised: 02 March 2020, Accepted: 27 March 2020

Published Online: 13 April 2020

In-Text Citation: (Sapai \& Ibrahim, 2020)

To Cite this Article: Sapai, A. H. A., \& Ibrahim, B. (2020). Rukhsah of Prayer for Officials of Flood Victims. International Journal of Academic Research in Business and Social Sciences, 10(4), 421-434.

Copyright: (C) 2020 The Author(s)

Published by Human Resource Management Academic Research Society (www.hrmars.com)

This article is published under the Creative Commons Attribution (CC BY 4.0) license. Anyone may reproduce, distribute, translate and create derivative works of this article (for both commercial and non-commercial purposes), subject to full attribution to the original publication and authors. The full terms of this license may be seen

at: http://creativecommons.org/licences/by/4.0/legalcode

Vol. 10, No. 4, 2020, Pg. 421 - 434

http://hrmars.com/index.php/pages/detail/IJARBSS

JOURNAL HOMEPAGE

Full Terms \& Conditions of access and use can be found at http://hrmars.com/index.php/pages/detail/publication-ethics 


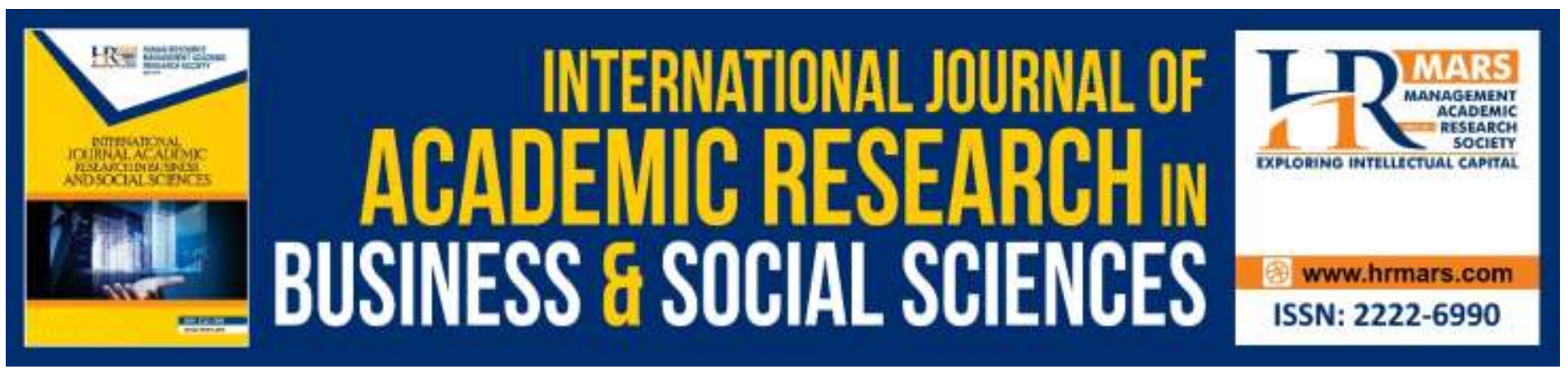

\title{
Rukhsah of Prayer for Officials of Flood Victims
}

\author{
Abu Hasan Ashaari Sapai ${ }^{1} \&$ Basri Ibrahim² \\ ${ }^{1}$ Universiti Islam Malaysia, Cyberjaya, Malaysia, ${ }^{2}$ Universiti Islam Malaysia, Cyberjaya, Malaysia/ \\ Faculty of Islamic Contemporary Studies, Universiti Sultan Zainal Abidin, Terengganu, Malaysia. \\ Email: ahas.ashaari@gmail.com
}

\begin{abstract}
Prayer is the pillar of religion obligated upon every accountable person to perform it five times a day. The obligation of performing prayer is constant with evidences from al-Quran and al-Hadith. It must be performed regardless of the situation either in ease or difficulty. Muslim community in Malaysia face difficult situation while encountering the disaster of critical flood striking the country each monsoon season especially in the states of Eastern Region in Malaysia Peninsula. In consequence of ignorance and unawareness Muslim community on rukhsah available in Islam in performance of prayer during flood disaster, some of them look down on the execution of prayer rituals and are confused with the implementation of rukhsah regarding prayer. This includes the officials assigned to rescue flood victims and provide facilities for them. This article aims to explain on rukhsah of prayer applicable by officials of flood victims during rescue of flood victims. Methodology implemented is of qualitative study. Data were collected through document analysis focusing on al-Quran, as-Sunnah, fiqh books of sect, books of Islamic jurisprudence principles (usul figh) and books discussing on rukhsah of prayer in details. Data collected were then analysed and discussed using several methods which were inductive, deductive and comparative methods. This study found that there are several forms of rukhsah for prayer applicable by officials of flood victims during tasks of rescue, assistance and treatment of flood victims. Among them, prayer by sitting and lying down, jamak and qasar for travelling officials, jamak prayer for settling officials, syiddatul khauf prayer, and prayer at the end of period. Comprehensively, conditions and situations faced by every officials of flood victims influence the forms of prayer rukhsah applicable by them.
\end{abstract}

Keywords: Rukhsah of Prayer, Officials of Flood Victims, Usul Fiqh, Fiqh, Jamak.

\section{Introduction}

Every year, Muslim people especially in Malaysia will be struck by monsoon season. Several states in the Eastern Region in particular will experience an unordinary rise of water level leading to major flood. Most of them who are involved with this flood phenomenon, are Muslim people, whose rituals are definitely affected especially for prayer. Among those involved are officials performing works of rescue and preparation of temporary settlement facilities for flood victims. Even though flood 
frequently strikes the states in Malaysia especially in the Eastern Region, their obligation of performing prayer is never dropped. Its performance is obligatory as long as they are sane regardless of the situation faced by them either in ease or difficulty. Only that for performance of prayer during flood for the officials assigned to rescue flood victims, there are rukhsah which have been discussed by scholars in their books, applicable by those officials. With that, obligation of prayer is not merely ignored by Muslim themselves due to rushing of assisting and facilitating flood victims.

Issue of implementation for rukhsah of prayer during flood is a critical research subject which must be attended by all parties due to flood phenomenon striking the country every year. Findings from a study by Subri et al. (2016), explained that interpretation from questionnaires performed to flood victims in year 2014 on the understanding of figh in flood evacuation centre, found that 1 to 3 respondent responded of extremely disagree and disagree to the question "I perform obligatory prayer even in facing flood situation". This showed that there were $5 \%$ to $16 \%$ from respondents surveyed who did not understand the obligation of performing prayer even in the condition of facing flood situation. Although the percentage were small, these data still indicated clearly that there were small group from the respondents who do not know and understand the issue of rukhsah for prayer during flood and this must be paid attention.

In other article, Subri et al. (2016) also pointed that there were $21.6 \%$ from his respondents who also raised the issue of obligatory prayer during questionnaires due to fiqh issues happening in flood evacuation centre in Pahang state. The percentage were among the highest after the issue of aurat exposure and mingling of men and women. The findings of this study explained that there are still flood victims transferred to flood evacuation centre who did not perform obligatory prayer until it was raised through questionnaires form posed. This indicated a worrying level of awareness on the issue of prayer performance among those who are involved in flood disaster, what more the involvement of officials of flood victims who are more exposed to the bustling situation for rescuing victims and channeling help.

Besides that, researcher found that authorised bodies such as Department of Islamic Development Malaysia (JAKIM), offices of Mufti and State Religion Councils, still do not possess an arranged and systematic guidelines regarding issue of prayer rukhsah for officials of flood victims despite the fact that this disaster is regular phenomenon happening in this country. Through broadcast from official website of MAIWP and other websites, researcher found that issue of rukhsah for prayer during flood only involves flood victims, not specific for officials of flood victims. Therefore, the function of these authorised bodies should be assisted to widen their function in developing studies in the field of prayer rukhsah for officials of flood victims to maximise the explanation of rituals issue to Muslim people in Malaysia.

Through master's thesis of Dyat (2010) titled Athar al-Taghayyurat al-Bi'iyyah fi Ahkam alIbadat al-Shar'iyyah Dirasah Fiqahiyyah Muqaranah, researcher could examine several issues and problems of rukhsah for prayer that can be made a basis of discussion on rukhsah of prayer for officials of flood victims. This thesis posed a discussion of scholars around figh issues affected by 
INTERNATIONAL JOURNAL OF ACADEMIC RESEARCH IN BUSINESS AND SOCIAL SCIENCES Vol. 10, No. 4, April, 2020, E-ISSN: 2222-6990 @ 2020 HRMARS

weather and climate change. Among the fiqh issues posed were issues of prayer, alms, pilgrimage and minor pilgrimage and several other issues.

Muda and Zin (2012), explained that there are to fiqh methods closely related to rukhsah issue which are ad-dharar yuzal and al-masyaqqah tajlibu at-taysir. Through these two methods come several other derived methods like al-amru iza dhaqan ittasa', al-amru iza ittasa' dhaqan, dar'u almafasid muqaddam 'ala jalbi mashalih, ma ubiihu lil dharurah yuqaddar bi qadariha and several other methods. Through these methods, researcher could take them as bases of putting emergency situation during flood faced by officials of flood victims, as a permission of implementing rukhsah of prayer.

Meanwhile, Syar'i (2011) in his article stated that on of usul al-fiqah scholars which was Abu Ishaq Ibrahim al-Shatibi, putting great attention to the role of rukhsah in propragating flexible Islamic laws. Rukhsah is a result of purification from values of life in a dynamic community. Through qualitative study, the study examined the thought of al-Shatibi thorugh al-Muwafaqat book describing the quality. Researcher could relate that the law of rukhsah is compatible with the dynamic property of sharia that can adapt with current condition like the flood situation in the country of Malaysia.

In the framework of rukhsah itself, it also discusses on the maslahah and dharurah that can determine the applicability of the rukhsah for prayer. For that, Rajab and Efrinaldi (2009) in Journal of Syariah presented a study titled Reconstruction of Maslahah Theory in the Study of Islamic Legislation Reformation: Analysis to Najm Al-Din Al-Tufi School of Thought. This study brought forward an analysis to maslahah theory posed by Najm Al-Din Al-Tufi implementing qualitative methodology in in collection of data and information. Through this study, researcher found that Najm Al-Din Al-Tufi school of thought towards the concept of maslahah and rukhsah was more contradictory compared to views by majority of scholars. Therefore, this point of view is important to make this study more holistic and encompasses all possible aspects.

The scope of this study is more focused on the question of rukhsah for prayer applicable to officials of flood victims. This is because, according to Mohamad (2017) in his small booklet Fiqah Musafir Solat Jama' \& Qasar explaining that he is more prone to say that it is not permissible for flood victims to perform jamak prayer as they are transferred to flood evacuation centre which is complete with facilities to perform prayer properly. Flood victims also do not own need that forces and constricts them that they need to implement rukhsah for prayer. Nevertheless, the situation differs with the officials who have to go into field to rescue and assist victims in flood disaster.

The above studies explained on the taking of rukhsah of prayer and its implementation among the flood victims but did not touch on the implementation of rukhsah for prayer for officials of flood victims who frequently spend full time to rescue flood victims and transfer them to temporary evacuation centre for flood victims. They also have to face various difficulties during their task. In consequent to that, this study aims to discuss the forms of rukhsah for prayer applicable by officials of flood victims during operation of rescuing and helping flood victims. 


\section{Research Methodology}

Methodology of this study was of qualitative study. Data were collected through document analysis comprising of al-Quran, al-Hadis, figh books, current fatwa journal articles related to the title of study. The data were analysed through inductive, deductive and comparative methods. This study focused more to rukhsahs of prayer applicable by officials of flood victims during task of rescuing and helping flood victims.

\section{Findings}

The findings can be looked through in the elaboration below

\section{Introduction of Rukhsah}

Rukhsah is a part of Allah SWT's blessings to His servants that His servants would not be burdened by matters unbearable by them. Allah SWT said:

Meaning: Allah would not burden a person except with something that he can bear. He will gain reward of what he puts effort on, and he also bears sins of what he puts effort on. (They pray by saying): "O our God! Do not You account us guilty if we forget or are mistaken. O our God! Do not You burden us with great burden as You have burdened to past people before us. O our God! Do not You put burden on us what we are unable to bear. And forgive our mistakes, and forgive our sins, and bestow blessings upon us. You are our Assistance; therefore, help us to gain success over the disbelievers".

(Al-Baqarah 2:286)

Ibn-Kathir (1999.1:737) explained that in the verse above, Allah SWT stressed that there is no one burdened to do something out of their capability. Allah bestows goodness and compassion upon them. Al-Qurtubi (2003.3:429) meanwhile stressed in his tafsir that Allah SWT does not burden the pauper with the taklif of rich people, as stated in His words.

Meaning: Should capable person give spending according to his capability; and those whose sustenance is stricken, then he must give spending of what Allah has bestowed upon him (as his capability); Allah does not burden somebody except of his capability that He has bestowed upon him. (Stricken people must remember that) Allah will grant ease after each difficulty.

(At-Talaq 65:7)

Al-Qurtubi (2003.3:429) stated that after difficulty is created, Allah will create ease and after difficulty, Allah will create relief. In other verse, Allah uttered on His promise, that with each difficulty that appears, there must be an ease besides it. He said,

Meaning: Then (steadfast on your belief) that truly with each difficulty comes ease.

That truly with each difficulty comes ease. 
Rukhsah is a word derived from Arabic word. There are several root words for this word like rakhsun and rukhsun, while jama' for this word is rukhas or rukhsatin. However, the word rakhsun is more acceptable by language scholars (az-Zabidi, 1965 17:595). Literally, meaning of rukhsah is to provide ease and leniency (Ibn-Manzur, n.d., 3:1616).

According to Kamus Dewan Bahasa dan Pustaka the Fourth Edition (2007), rukhsah is the leniency lined by sharia due to emergency state such as permission of eating carcass, reducing number of rakaats during travel, breaking fast due to sickness and others.

Definition of rukhsah from technical aspect meanwhile involves several views of scholars.

\section{Definition of Rukhsah According to Scholars of Hanafi Sect}

According to al-Sarakhsi (t.th.1:118) rukhsah is a law permissible on account of excuse or masyaqqah but in the maintenance of its evidence and law of prohibition. Ibn-Humam (n.d, 2:228) meanwhile opined that, rukhsah is a law decreed to achieve the leniency taken from the evidences permitting laws of the leniency due to excuse.

The law decreed for this leniency purpose is intended to prevent or avoid from the original law which is the 'azimah law due to existence of proof for excuse permitting an accountable person to leave the original law. For example, a sick person permitted to break his fast. The existence alMaradh reason which is the sickness proved by expert or specialist of its existence, has permitted an accountable person to leave the obligation of fasting in the month of Ramadan.

According to Haidar $(2003,1: 35)$ rukhsah a law widened from its law of prohibition by sharia proof due to existence of excuses widening it from the hardship. Meanwhile, the excuse itself according to scholars of Hanafi sect must be known of its existence or agreed by expert that it is an excuse acceptable as a real excuse able to drop the original law.

\section{Definition Rukhsah to Scholars of Maliki Sect}

According to al-Syatibi (1997.1:466), rukhsah means a law decreed due to an excuse permitting exception of law from the original law. The permissibility is only applied in certain places needful of it.

The law decreed due to existence of excuse is meant to avoid or change the law bound by existence of masyaqqah, where in inexistence of masyaqqah the law of rukhsah is inapplicable and and not named as rukhsah. For example, a person voided of travel, is not permissible to shorten or gather prayers anymore instead he must complete his prayer according to original law. It is the same as a person who is not allowed to break his fast after void of travel or recovery from sickness. 
INTERNATIONAL JOURNAL OF ACADEMIC RESEARCH IN BUSINESS AND SOCIAL SCIENCES Vol. 10, No. 4, April, 2020, E-ISSN: 2222-6990 C 2020 HRMARS

\section{Definition of Rukhsah According to Scholars of asy-Syafi'i Sect}

Al-Baidhawi (2008:58) defined rukhsah as a law decreed through proof contradicting with other proofs due to existence of excuse. The meaning of excuse itself refers to the existence of masyaqqah and hajah which is the existence of hardship and need such as sickness or need of travel.

From the elaboration above, Rukhsah can be summarized as a leniency permitted by sharia when an accountable person is facing hardship and need; refer al-Baidhawi, (2008.1:58). The hardship and need are measured with current condition faced by the accountable person. To look at the difficulty contained in the title of this study, it must be referred to the condition of officials of flood victims involved in operation of rescuing and helping flood victims itself.

\section{Introduction of Rukhsah for Prayer}

The five times prayer is an obligation obligated of performance by each individual. The obligation does not drop in any situation, instead it is obligatory to be performed perfectly. However, in the situation of hardship and need, obligatory prayer is performed as usual. In exception that he is allowed to take rukhsah in performing the prayer. Rukhsah of prayer means leniency and concession given by sharia during the performance of prayer such the four-rakaat prayer becomes two-rakaat prayer, which is performed separately according to its respective period or gathered with the period of other prayer either in the first period or second period and others. According to (2010), leniency is decreed by Islam to ease Muslim people to perform rituals while facing situation of hardship, difficulty, threat and others.

\section{Original Concept of Law of Prayer and Its Implementation}

The original law of prayer is obligatory as said by Allah SWT.

Meaning: Then when you have finished performing prayer, then you must say and remember Allah while standing or sitting, and while lying down. Then when you feel secure (in a secure state) then perform the prayer (perfectly as usual). Truly the prayer is a decree obligated upon the believers, which time is fixed.

(An-Nisa' 4:103)

Said Allah SWT more,

Meaning: "Truly I am Allah; there is no God but Me; therefore, worship Me, and perform prayer to remember Me.

(Taha 20:14)

The performance of prayer itself is divided into five times which are period of Subuh, Zohor, Asar, Maghrib and Isyak. For condition permitting rukhsah, Subuh and Maghrib prayer respectively is obligatory to be performed as tamam which sticks to two and three rakaats. Meanwhile for Zohor, Asar and Isyak prayer can be shortened of it fulfills the condition of qasar prayer such involving journey of more than two marhalah which is a journey of 81 kilometres and above and person involved in the journey does not intend to settle in a place more than the day rate allowed for qasar. This permissibility is found in words of Allah SWT: 
Meaning: And when you travel on earth, then you are not sinful "to do qasar" (to shorten) prayer if you are afraid of being attacked by the disbelievers. Truly the disbelievers are obvious enemy of you.

(An-Nisa' 4:101)

Meaning of qasar in the verse above is shortening four-rakaat prayer to two rakaats. Besides that, meaning of qasar in the verse above is a leniency for performance of prayer pillars which is during a travel threatened by enemy or facing a fearful situation (khauf), (al-Zuhaili, 1994 1:95-96). It is also related to leniency of performing the pillars of four-rakaat prayer while encountering fear situation while in the hometown (hadar).

Rukhsah of prayer is also given to person who are forced to leave several pillars in the prayer such as inability of standing up during prayer by performing it by sitting or lying down according to degree of pain or harm existing on the moment. Besides that, rukhsah of prayer is also found in the issue of purification (taharah) which is when a person could not find water to purify and allowed to perform prayer through dry ablution which is by using dust to replace water (Mohamad, 2016.1:60).

\section{Flood Situation}

For flood situation happening in Malaysia, according to observation performed by the researcher, it can be categorised into two situation which is first normal flood category and second critical flood. Normal flood refers to the situation where water level exceeds normal water level and causing flood but still does not threat life and safety of residents and flood victims. Situation for this flood category still can be managed in secure and peaceful condition such as transferring flood victims and providing emergency help to flood victims. Rituals also can be performed normally and do not involve taking of rukhsah for prayer.

Meanwhile, critical flood situation meanwhile refers to situation of water level exceeding normal level causing major flood and threatening life and safety of residents such as major flood submerging the whole village, or flood accompanied by lightning and loud thunder and flood accompanied with earthquake and others. This situation causes flood victims to be transferred immediately and officials of flood victims must be careful in this situation that they will not get involved in any unwanted incident. Flood in this situation needs officials of flood victims to take rukhsah during prayer performance (Rahman (2010).

\section{Forms of Rukhsah for Prayer During Flood}

By examining the critical flood situation striking the country and by scrutinizing discussions of scholars on rukhsah of prayer, there are several forms of rukhsah applicable by officials of flood victims.

\section{Prayer by Sitting or Lying Down}

For officials of flood victims having injury during operation of rescuing and helping flood victims, they are permitted to perform prayer by sitting or lying down. This is constant with hadis narrated by Imran bin Husain RA: 
INTERNATIONAL JOURNAL OF ACADEMIC RESEARCH IN BUSINESS AND SOCIAL SCIENCES

Vol. 10, No. 4, April, 2020, E-ISSN: 2222-6990 C 2020 HRMARS

Meaning: Perform prayer by standing. If not able, then by sitting. If still not able, then by lying on the ribs.

(al-Bukhari:1117)

Officials having injury preventing them from praying by standing, can perform it by sitting. If they are not able to perform by sitting, then he can perform by lying on ribs as his capability.

\section{Jamak and Qasar Prayer for Travellers}

For officials of flood victims who are not settlers, they are permitted to perform jamak and qasar which are by gathering two prayers in a period and shortening four-rakaat prayer to two rakaats. Qasar prayer is permissible to those who fulfill certain conditions. Among the conditions mentioned by Bugha (1992.1:185-187), the first is being in travelling condition. The obligatory prayer to be performed must have already entered its period while being in travelling condition. It is not permissible for officials of flood victims who still have not begun their journey to perform jamak and qasar. Also that they are not permitted to perform jamak and qasar for the prayer that has already entered its period during travel but they still do not perform it until return into their hometown.

Second, they must cross the boundary of qariah which is crossing of village boundary. This is compatible with the hadis narrated by Anas bin Malik r.a, explaining:

Meaning: Prophet SAW performed Zohor prayer in Madinah as four rakaats and performed Asar prayer in Zulhulaifah as two rakaats.

(al-Bukhari:1547; Muslim:690)

Zulhulaifah was a place outside Madinah city. The hadis above explains that Prophet SAW had shortened the prayer after being outside of his qaryah area which is Madinah.

Third, travelling officials of flood victims are not permitted and not valid of having a settling imam who prays the prayer as tamam while the travelling makmum prays as qasar. For officials of flood victims being in the operation centre with mixture of travelling and settling officials, they must choose a travelling imam if they are to perform qasar prayer.

Fourth, officials of flood victims cannot intend of settling in the evacuation centre more than four days. According to Imam An-Nawawi, (2008.1:128), person who intends to settle (stay) for 4 days in a place, his travelling condition is voided without counting the duration of arriving and departing according to authentic view. According to Jalaluddin al-Mahalli, (2013.1:270) the existence of a person in a place for three days (not exceeding four days), does not expend somebody from law of travel.

For officials of flood victims tasked in a rescue operation which end of it is unknown, they can perform, they can perform the jamak and qasar for 18 days. Ths subject was explained by al-Nawawi (2008.1:128). 
INTERNATIONAL JOURNAL OF ACADEMIC RESEARCH IN BUSINESS AND SOCIAL SCIENCES

Vol. 10, No. 4, April, 2020, E-ISSN: 2222-6990 (C) 2020 HRMARS

"If a person stays in a state with intention of leaving the state after the objective and need has been completed as expected, he can perform qasar every period for 18 days. Another view is for 4 days and another says that it is permissible for qasar forever".

According to al-Mahalli (2013.1:271), for scholars of al-Syafi'I sect, it is permissible to perform jamak and qasar prayer for 18 days as long as those involved do not know the end time of their task or need based on hadis narrated by Imam Abu Daud:

"From Ibn Abbas that Rasulullah SAW performed prayer as qasar in Mekah for 17 days."

(Abu-Daud: 1230)

\section{Jamak Prayer Despite Settling}

For settling officials of flood victims, they cannot take rukhsah as travelling officials of flood victims as they do not fulfill the conditions of travel permitting them to perform jamak and qasar. However, there are two categories of leniency practicable by settling officials of flood victims. First, jamak prayer due to need or emergency. According to al-Baidhawi (2008.1:58) rukhsah is a law permitted based on evidence where the law contradicts existing evidence due to an excuse. Al-Baidhawi believed that excuse refers to existence of masyaqqah and hajah.

According to Al-Qarafi (1993:87), discussion of law of excuse and leniency must be based on clear and lucid point and evidence as decrement of leniency law itself contradicts with evidences decreeing original law such as performing prayer in its period. Allah SWT said,

Meaning: Then when you have finished performing prayer, then you must say and remember Allah while you are standing or sitting, and while lying down. Then when you feel secure (in a secure) then perform the prayer (perfectly as usual). Truly the prayer is a decrement obligated upon the believers, which time is fixed.

(An-Nisa' 4:103)

Besides that, Imam Muslim narrated hadis from Ibn Abbasexplaining that Prophet SAW had performed jamak prayer while not travelling and not in threat.

Meaning: Rasulullah SAW performed jamak prayer between Zohor and Asar, and Maghrib and Isyak in Madinah in cthe condition of no fear and no rain. Ibn Abbas was asked: Why did he do like that? Ibn Abbas answered: Rasulullah SAW did not want to burden his people.

(Muslim:705)

Based on the explanation above, critical situation faced by officials of flood victims focusing on effort of rescuing flood victims becomes the main reason permitting them to gather two prayers in a period. Indeed, in rescue operation, there must be rushing to mobilise operation of saving the lives of flood victims. 


\section{Jamak Prayer during Heavy Rainfall}

hile on duty during flood situation involving continuous rainfall, settling officials of flood victims can gather prayer due to rainfall in the first period between Zuhur and Asar, Maghrib and Isyak. This is based on hadis narrated by Ibn Abbas r.a:

Meaning: Prophet SAW performed prayer in Madinah for seven and eight rakaats (as jamak) between Zohor and Asar and between Maghrib and Isyak. Ayub al-Sakhtiani said: It might happen during a night raining heavily.

(al-Bukhari:543; Muslim:705)

Indeed, majority of scholars permitted the performance of jamak during heavy rainfall based on the above hadis. According to what said in Mausu'ah Fiqhiyyah al-Kuwaitiyyah (1989 15:289), performing jamak prayer during rainfall is conditioned as follows:

a. Jamak performed must be of jamak takdim which is praying in the first period.

b. Rainfall must be continuous beginning from takbiratul ihram of the first and second prayer and still continuing until salam for the second prayer.

c. Only permitted to be performed at the mosque congregationally and imam must perform prayer intending of jamak takdim. This view is the view of scholars of al-Syafi'i and Maliki sect, while for view of Hanbali sect it is allowed for the prayer to be performed at home or at the mosque, personally or congregationally; refer Mausu'ah Fiqhiyyah alKuwaitiyyah (1989.15:290)

\section{Prayer in Syiddah al-Khauf Condition}

Khauf prayer is a prayer performed by leaving several main pillars of prayer as there is possibility while performing the prayer that threat like enemy threat during war or during natural disaster such as flashflood or earthquake.

Abu-Syuja' (2011.1:14), explained that it is permissible to perform prayer without facing kiblat while in an extremely fearful condition (syiddatul khauf) and during supplementary prayer during journey and on vehicle. Khauf prayer is discussed from various conditions practicable and indeed according to several figh books, it involves 11 to 13 conditions. However, khauf prayer is only specific for situation of highly-harmful threat, either to life or body. For example, while performing prayer during flashflood or earthquake, at the moment it is permissible to continue praying by skipping pillars of prayer such as by not facing kiblat, not performing bowing and prostration perfectly. In the condition, prayer is accounted valid from scholars' view, even in the running condition.

\section{Jamak Suri Prayer at the End of the First Period and Beginning of Second Period}

Intentionally delaying prayer without reason is considered sinful by several scholars. However, in needful condition, it is allowed to delay prayer while still in the period of the prayer. In al-Syafi'i sect there is jamak suri prayer in which a person having excuse can perform obligatory prayer at the end of the first period and beginning of the second period (al-Nawawi, 1980.3:26). 
Besides that, period for performance of prayer can be divided into five which are preferred period, optional period, permissible period, disapproved period and forbidden period. As long as a person still gets a chance to perform the prayer in its period even in forbidden period, the status is still valid if he gets to perform a rakaat (Al-Zuhaili, 2011.1:168-171). According to Al-Zuhaili (2006.1:312) more, performance of prayer can also be divided into two parts of obligation which are first wajib mudhayyaq (obligation of constricted and short time of performance) and second wajib muwassa' (obligation of wide and long time of performance). Therefore, in flood situation faced by officials of flood victims, forcing them to perform responsibility of rescuing victims and providing help, they are permitted to delay and adjourn prayer at the end of period and perform the next prayer at the beginning of period. However, it must be detailed, if the officials are not burdened by heavy task or responsibility and allowing them to perform prayer at early period, they should perform prayer immediately and not delaying without reason. This is compatible with hadis of Rasulullah SAW narrated by Abdullah bin Mas'ud RA, saying:

Meaning: A man asked Prophet SAW, what is the most main deed to be practised. He answered: Performing prayer at early period. (al-Bukhari:6980)

\section{Conclusion}

Islam is a religion of blessing to the whole world which its laws are arranged coinciding with the nature of human. Taklif commanded is a symbol of ta'abbudi of a servant to his God who has bestowed all bounties to His servants. The decrement of rukhsah meanwhile is a symbol of ar-Rahim attribute of Allah SWT to His servants, by giving leniency in obeying all His commands. In Islam, skipping prayer is a major sin and prohibited, as Prophet SAW said in hadis narrated by ummu Aiman RA:

Meaning: If you intentionally skip prayer, truly who intentionally skip prayer, he will lose protection from Allah and His messenger."

(Ahmad:26098)

Therefore, it is not permissible for an official of flood victims who is Muslim, sane-minded and has reached puberty to skip prayer as Islam has lined certain rukhsah to ensure that the responsibility is performed in any condition.

Rukhsah is a decrement concept that widens the implementation of sharia while Muslim people are facing hardship and masyaqqah. Implementation of rukhsah during flood situation by officials of flood victims is important to avoid skipping of prayer from happening among them.

There are some forms of rukhsah for prayer applicable by officials of flood victims depending on the situation faced by them which are performing prayer by sitting and lying on ribs for officials having injury that prevents them from standing up literally, performing jamak and qasar prayer as a whole either as jamak taqdim or jamak $t a^{\prime}$ khir for officials of flood victims experiencing long journey or travel, gathering two prayers even not in a travel due to condition of need and emergency faced, 
INTERNATIONAL JOURNAL OF ACADEMIC RESEARCH IN BUSINESS AND SOCIAL SCIENCES

Vol. 10, No. 4, April, 2020, E-ISSN: 2222-6990 @ 2020 HRMARS

jamak prayer at the mosque congregationally during continuous rainfall, prayer in syiddah al-khauf condition or fearful situation and jamak suri prayer.

Therefore, it is hoped that this study will become a catalyst to further studies in widening the study on implementation of rukhsah for prayer while facing flood situation. This can also facilitate in building understanding and awareness among officials of flood victims and preventing them from ignoring the prayer obligated to every Muslim.

\section{Corresponding Author}

Abu Hasan Ashaari bin Sapai, Universiti Islam Malaysia, Cyberjaya, Malaysia.

Email: ahas.ashaari@gmail.com.

\section{Acknowledgement}

Special thanks to the Majlis Agama Islam Dan Adat Istiadat Melayu Perlis for funding the research under Jamalullail Professorial Chair, Universiti Islam Malaysia.

\section{References}

Latif, M., \& Rosmawati, A. (2012). Usul Fiqh \& Kaedah Fiqh. Pustaka Salam. Kuala Lumpur.

Rahman, S. N. D. (2010). Athar al-Taghayyurat al-Bi'iyyah fi Ahkam al-lbadat al-Shar'iyyah Dirasah Fiqahiyyah Muqaranah. Tesis Sarjana. Jami'ah al-Islamiyyah bi Ghazzah (Universiti Islam Gaza).

Abu-Syuja', A. H. A. A. (2011). Al-Ghayah wa At-Taqrib Matan Abi Syuja'. Maktabah Jumhuriyyah alArabiyyah.

Al-Baidhawi, N. A. B. U. (2008). Minhaj Wushul ila Ilmi Ushul. Bab Ta'rif Rukhsah Wal 'Azimah. Dar Ibn Hazm, Beirut. V. 1, P. 58.

Al-Bukhari, M. I. I. M. (2012). Sahih al-Bukhari. Dar at-Ta'seel, Kaherah.

Al-Hanbal, A. M. H. (2001). Musnad al-Imam Ahmad bin Hanbal. Bab Hadis Ummu Aiman. Muassasah ar-Risalah, Beirut. No. hadith 27364. V. 45, P. 358.

Ali, H. (2003). Durarul Hukkam Syarh Majallah al-Ahkam. Topik al-Masyaqqah Tajlibu at-Taysir. Darul 'Alim Kutub, Beirut. V. 1, P. 35.

Al-Jistani. A. D. A. (n.d). Sunan Abi Daud. Kitab Solat as-Safar. Baitul Afkar ad-Dauliah, Riyadh. H. 149. Al-Mahalli, J. M. A. M. (2013). Kanzu Ar-Raghibin. Dar al-Minhaj, Jeddah. V. 1, P. 270-271.

Al-Muslim, M. H. Q. N. (2014). Sahih Muslim. Dar at-Ta'seel, Kaherah.

Al-Qurtubi, M. A. A. B. (2003). Al-Jami' li Ahkam al-Quran. Dar Alim al-Kutub, Riyadh. J. 3, h. 429.

Al-Nawawi, A. Z. M. Y. S. (1980). Al-Majmu' Syarah Muhazzab Li Syairazi. Dar as-Salam, Kaherah. V.3, P. 26.

Al-Nawawi, A. Z. M. Y. S. (2008). Minhaj at-Thalibin. Dar al-Minhaj, Jeddah.

As-Sarakhsi, M. A. A. S (n.d) Ushul as-Sarakhsi, Dar al-Ma'rifah, Beirut. V.1, P.118.

As-Syatibi, I. M. M. (1997). Al-Muwafaqat. Dar ibn-Affan.

Az-Zabidi, M. M. A. R. (1965). Taajul 'Urus. Darul Hidayah. V. 17, P.595.

Az-Zuhaili, M. W. M. (1994) Tafsir al-Wajiz. Dar al-Fikri, Damsyik, P. 95-96.

Az-Zuhaili, M. W. M. (2006) Al-Wajiz : Ushul Al-Fiqh Al-Islami. Dar al-Khair, Beirut.

Az-Zuhaili, M. W. M. (2011) Al-Muktamad Fil Fiqhi As-Syafie. Dar al-Qalam, Damsyik. V. 2, P. 168-171. 
INTERNATIONAL JOURNAL OF ACADEMIC RESEARCH IN BUSINESS AND SOCIAL SCIENCES

Vol. 10, No. 4, April, 2020, E-ISSN: 2222-6990 @ 2020 HRMARS

Ibn-Humam, K. M. A. W. (n.d). Tahrir fi Ushul al-Fiqah bi Syarh al-Taqrir wa at-Tahbir. Dar al-Kutub al-Alamiah, Beirut.

Ibn-Kathir, I. U. K. Q. (1999). Tafsir al-Quran al-'Azim. V. 1, P. 737.

Ibn-Manzhur, J. M. M. (n.d). Lisanul 'Arab. Darul Ma'arif, Kaherah. V.3, P.1616.

Irwan, M. S. (2016). Isu-Isu Fiqah Di Pusat Pemindahan Mangsa Banjir: Kajian Perintis Di Daerah Temerloh, Pahang. Jurnal INFAD, (8): 29-48.

Irwan, M. S. (2016). Kefahaman Fiqah Di Pusat Pemindahan Mangsa Banjir: Kajian Perintis Di Daerah Temerloh Dan Maran, Pahang, Jurnal INFAD, (8): 91-107.

Khairunnas, R. E. (2009), Rekonstruksi Teori Maslahah Dalam Kajian Pembaharuan Perundangan Islam: Analisis Terhadap Pemikiran Najm Al-Din Al-Tufi, Jurnal Syariah, 17(3), P. 593-606.

Khairuldin, W. M. K. F. B. W., Embong, A. H., Hassan, S. A., Yasin, M. F. M., \& Anas, W. N. I. W. N. (2019). Strategic management in fatwa-making process. Academy of Strategic Management Journal, 18(4), 1-6.

Khairuldin, W. M. K. F. W., Anas, W. N. W. I. N., Embong, A. H., Hassan, S. A., Hanapi, M. S., \& Ismail, D. (2019). Ethics of mufti in the declaration of fatwa according to islam. Journal of Legal, Ethical and Regulatory Issues, 22(5), 1-6.

Yasin, M. F. B. M., Embong, A. H., Khairuldin, W. M. K. F. W., Rahim, A., Abdullah, Sulaiman, R., Mutalib, N. A. (2018). Contributions of technology towards development of Qur'anic tajweed knowledge. International Journal of Civil Engineering and Technology, 9(6), 1340-1352.

Makmun, S. (2011). Akar Sejarah Pemikiran Al-Shatibi Tentang Rukhsah. Jurnal Islamica. 6(1): 87-103.

Mustafa, B. (1992). Fiqah al-Manhaji Mazhab al-Syafie. Dar al-Qalam, Beirut. V. 1, P. 185-187.

Umar, M.M.N. (2016), Al-Kafi Li Al-Fatawi 181: Jamak Solat Ketika Banjir, akses 20 April 2019, http://www.muftiwp.gov.my.

Kuwait, Wuzarah, Al-A. W. S. Al-I. (1989). Mausu'ah Fiqhiyyah al-Kuwaitiyyah. Dzatul Salasil, Kuwait. V. 15, P. 289-290.

Zulkifli, M. (2016). Ghayah Al-Murtaja : Syarah Safinah an-Najah. Batu Caves, Selangor. PTS Publications.

Zulkifli, M. (2017). Fiqah Musafir : Solat Jama' \& Qasar. Nilai, Negeri Sembilan. Pustaka Cahaya Kasturi. 